\title{
THE TECHNOLOGY OF SOCIAL NETWORKS AND PEOPLE MANAGEMENT IN THE RECRUITMENT AND SELECTION OF ITS EMPLOYEES
}

\section{ORIGINAL ARTICLE}

SUMAR, Ramiro Rodrigues ${ }^{1}$

SUMAR, Ramiro Rodrigues. The technology of social networks and people management in the recruitment and selection of its employees. Revista Científica Multidisciplinar Núcleo do Conhecimento. Year 06, Ed. 07, Vol. 12, pp. 7490. July 2021. ISSN: 2448-0959, Access Link: https://www.nucleodoconhecimento.com.br/business-administration/employees, DOI: 10.32749/nucleodoconhecimento.com.br/business-administration/employees

\section{ABSTRACT}

Objective: To describe the impact that social networks can have on the recruitment and selection of their employees. Question Problem: How can the social network favor the recruitment and selection of employees of a company? Methodology: Literature review. Results: The evidence of the results showed that technologies through social networks can be relevant for the recruitment and selection of people for the organization. But this recruitment should be done with a differentiated look at each type of social network by the recruiter. Final Considerations: Recruitment and selection have been changing as a traditional (face-to-face) way for the technological (virtual) mode. The study mentioned that social networks are tools capable of bringing to the recruiter candidates able to take the organization responsibly and that there are no barriers in the virtual world to find the ideal candidate. It is emphasized the importance of extending this study based on scientific evidence, in which

\footnotetext{
${ }^{1}$ Master's degree in Controllership, Specialist in Technology Management, Strategic Administration, Information Security and Graduated in Accounting Sciences.
}

RC: 93820

Disponível em: https://www.nucleodoconhecimento.com.br/business- 
research can be carried out in companies for the use of social networks in the monitoring of their employees.

Keywords: People management, Social networks, Information technology and communication.

\section{INTRODUCTION}

Companies have in their main goals to obtain results, however, for this to happen, the first step is to hire qualified and competent professionals to be part of the team. Among the departments that make up a company there is the part of human resources management, which has as one of its functions to recruit for the organization its professional staff (CARVALHO, 2015).

The word "Manage" consists of the decision-making process and the realization of actions (whether collaborative, to improve resources, interaction, among others) so that the objectives desired by the company can be achieved (COSTA, 2018). Therefore, the focus of human resources management (or people management) is related to the performance of skills, among them: efficiency, effectiveness, productivity, satisfaction and commitment to people, survival of the organization, quality, competitiveness and social responsibility (SPADER, 2019).

The manager needs to have several qualities to be able to list his company, among which are to leadership, responsibility and empathy to mediate the performance of his employees, for this he needs to know how to listen and be open to suggestions, be participatory, and get involved, mainly, in the tasks seeking to be complicit in the delegation of these (DE BEM NORO; STUKER; DE OLIVEIRA, 2015).

According to Ribeiro (2017), the human resources manager or, people manager, besides being qualified for the position, must have tools (performance evaluation; continuous feedback; information and communication technologies, among others),

RC: 93820

Disponível em: https://www.nucleodoconhecimento.com.br/business- 
necessary for the achievement of good administration, considering that the human resources part is where various processes will be executed so that the company can guarantee its name in the business market, processes that aim to recruit employees to complete the organizational system.

This recruitment takes place in several forms, the most used today is through technologies. The technological era for organizations comes with the objective of improving quality in service bringing speed in the development of products / services, reliability in business data, greater performance by employees among other qualities and, ensuring more safety to its users. In people management, technologies favor a greater reach of people to be recruited, besides also helping the manager in the moment of really knowing the personal life of his employees (SILVA, 2019; PORTO et al., 2016; SANTOS, 2018).

According to Motta et al. (2017), the worldwide network of computers (internet) favors that the relationships between employees and managers can build new cultures of relationship and knowledge, which can result from the knowledge and information derived from internet access, with more intensity of social networks accessed or not in the work environment.

It is essential to have the understanding that people management has been playing an important role within organizations. This role is modeled not only on policies and practices, but also seeking to highlight in organizational factors related problems such as: tensions between workers, poor organization within the work environment, cultural problems characterizing prejudice, in order to be able to control the damage caused by a possible moral harassment and that will affect the entire organization of the company (LEAL; MATOS; FONTANA, 2013).

The study in question brings to the fore the importance of technologies for the recruitment and selection of employees who seek to work in an organization. The justification of this study comes from the researcher having experience in information

RC: 93820

Disponível em: https://www.nucleodoconhecimento.com.br/business- 
and communication technologies and observing that in social networks the offer of employment arises with a very significant demand, as well as the observation of the way the interview will be held (especially people of higher level the interview takes place by google meet). In this segment, the problem question of this study is: How can the social network favor the recruitment and selection of employees of a company?

Therefore, the main contribution to the realization of this study is based on the knowledge about the use of technologies by people managers, from social networks, making it relevant to add greater knowledge to both the professional and the general society. For the scientific community, the study has its relevance added to the expansion of knowledge about the use of technologies for the recruitment and selection of people.

The objective proposed in this study was to describe the impact that social networks can have on the recruitment and selection of their employees.

For this study to take place, we sought a theoretical basis related to the following themes: Recruitment and selection in the company; information technologies impacting on people management; Social networks for the recruitment and selection of a company.

Based on this theoretical basis, the study design has its methodology based on the bibliographic review.

RC: 93820

Disponível em: https://www.nucleodoconhecimento.com.br/business- 


\section{THEORETICAL REFERENCE}

\subsection{THE ROLE OF RECRUITMENT AND SELECTION IN THE COMPANY}

Speaking of recruitment and selection of people, Oliveira and Bueno (2018) describe that this system of choice comes from cavemen, where people's choices to develop the attributions imposed by the social system of the time were given by their strength, being the strongest condition ed to participate in the hunts for the feeding of their people. In the current context, this selection is becoming increasingly difficult.

Chiavenato (2002) mentions the importance of recruitment and selection for the organization. The author reinforces that both organizational choice tools are directly linked to the development of the company and, even having different attributions, has the same objective: To identify the appropriate employee to make up the organization.

Recruitment can be classified as internal or external. Recruitment being internal happens when the organization makes a change to its staff. This change results from the performance of the worker in his sector and the need of the company, which allows the choice of this worker who has been observed for some time, from the promotion, that is, transferring them to departments or positions with greater prominence. From this modification this employee is trained, so that his performance can achieve better results within the company with his activities (CANALLI; DE ANDRADE, 2016).

In the recruitment externally, the employee can be chosen through processes or by other means. Examples in relation to these media are announcements in the press, lectures in schools and universities, dissemination in class associations, by recommendations of third parties, employment agencies, candidate files stored in the company that have already presented themselves and exchange of companies. In

RC: 93820

Disponível em: https://www.nucleodoconhecimento.com.br/business- 
external recruitment, ads from the company and by pages of dissemination of vacancies on the Internet bring this notoriety that employees are needed (SILVA; FERRETT; MANCINI, 2014).

Therefore, all the company's efforts to bring to its circle new employees are related to recruitment. Alberton, (2002), describes that the recruitment process is considered one of the most important stages of the admission process of a new professional. The author reinforces that most companies search in the foreground within the internal environment, and then go to the labor market.

Mozer (2016) reinforces that the organization has different cultures from each other. These cultures can cause the work to be done in different ways. However, recruitment and selection are no different. The process by which the recruitment of the organization is carried out has its variations, but the means used are the same, and can be through information and communication technologies, where vacancies are disclosed for positions within the company. In the case of selections, there is a decision by which the candidate will position himself from the best performance to the position offered to him.

Both recruitment in internal or external form has its advantages and disadvantages. For the organisation as well as for the competitors to the position made available in the company, these conditions should be examined to identify the best way to recruit. Figures 1 and 2 make a statement of these advantages and disadvantages of internal and external recruitment.

RC: 93820

Disponível em: https://www.nucleodoconhecimento.com.br/business- 
Figure 1: Advantages internal and external recruitment

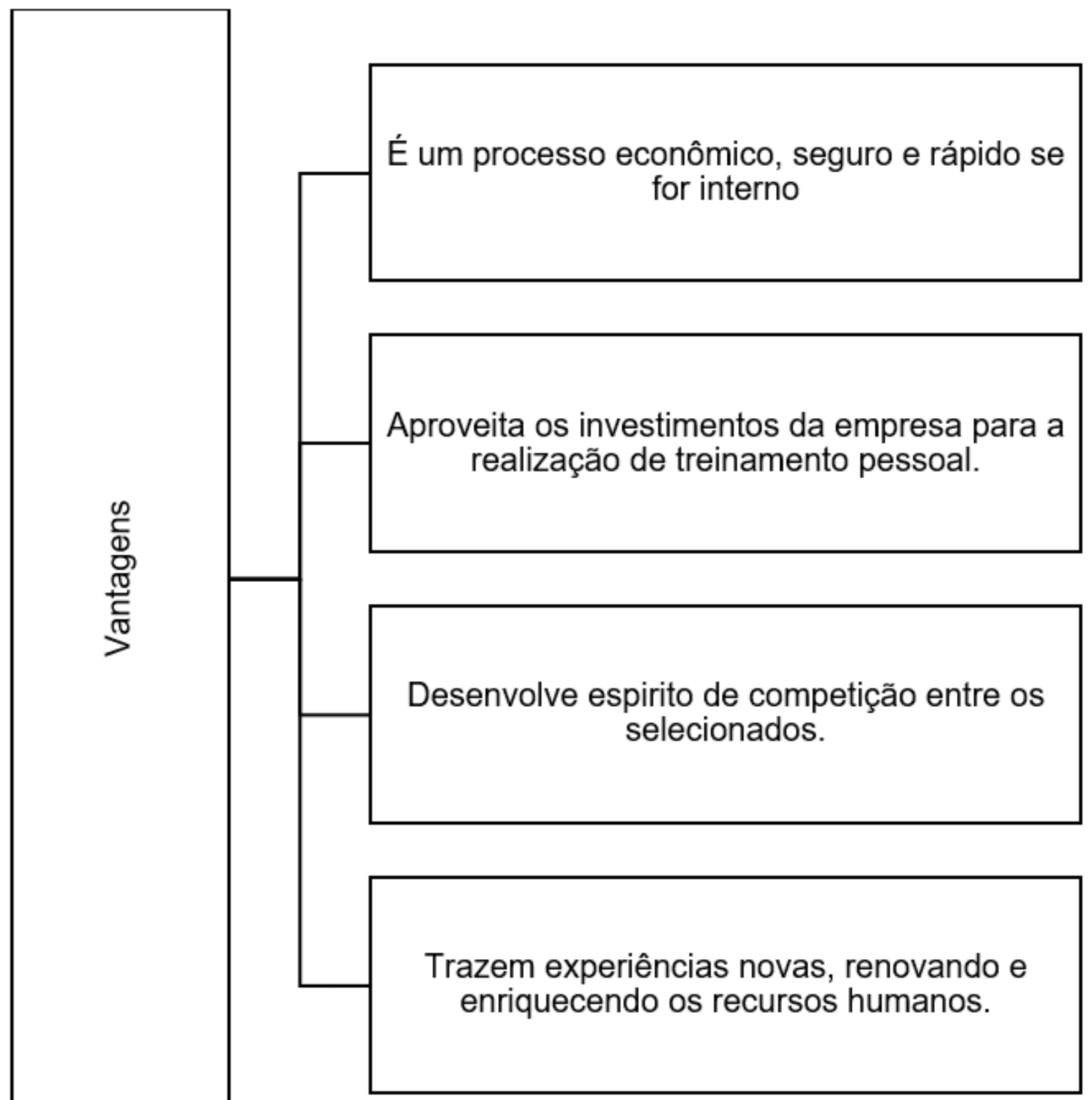

Source: Taken from Chiavenato (2002).

RC: 93820

Disponível em: https://www.nucleodoconhecimento.com.br/business- 
Figure 2: Disadvantages of internal and external recruitment

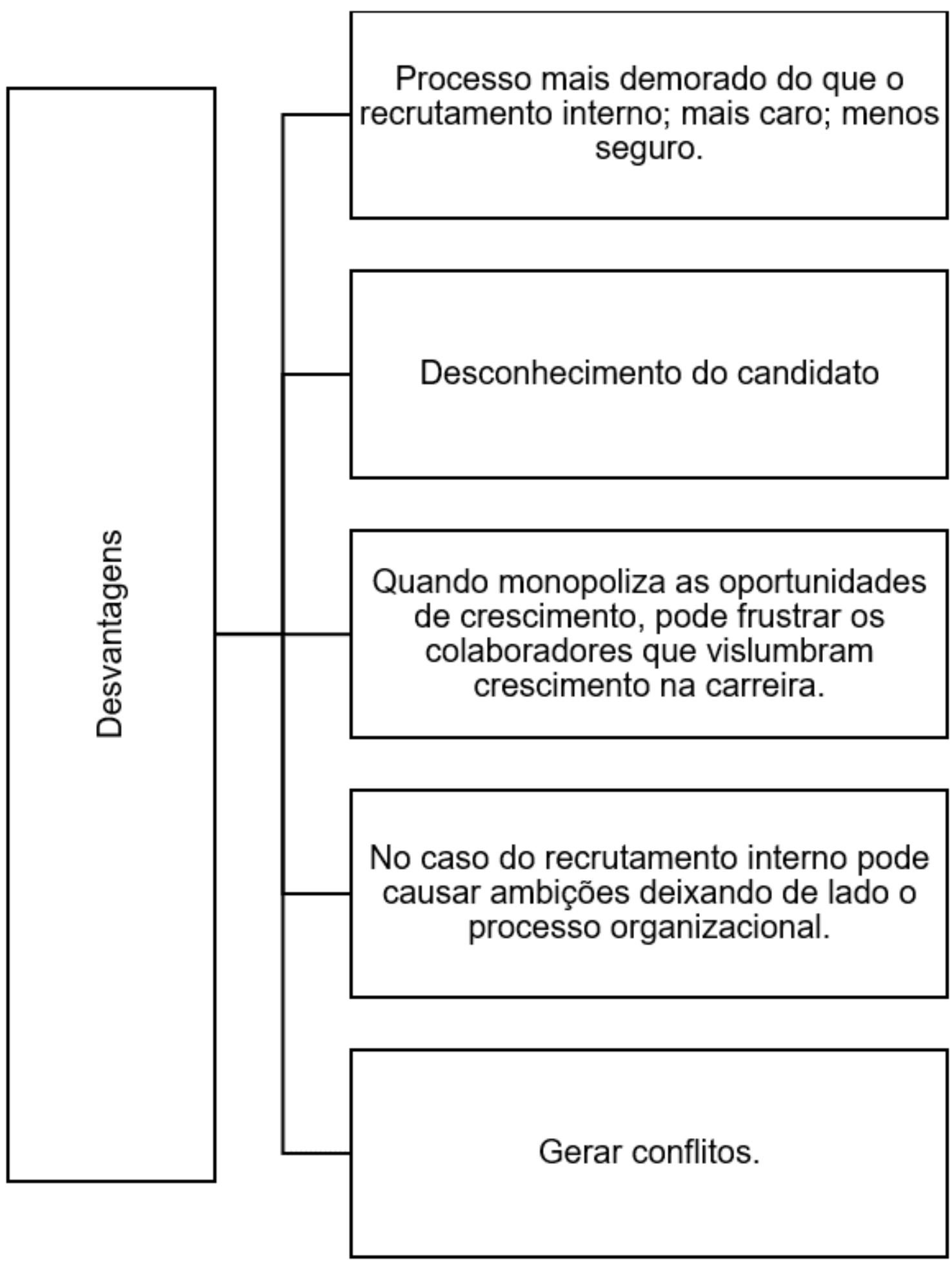

Source: Taken from Chiavenato (2002).

RC: 93820

Disponível em: https://www.nucleodoconhecimento.com.br/business- 
Therefore, recruitment and selection are tools in which companies are willing to invest, adding value to contractors. Thus, the selected employees must be able to perform the function for which the vacancy competed, and know the policies that the company adopts.

Chiavenato (2002) states that these tools can be used in parallel. The choice of how it should be used will depend on the situation, number of candidates, desired profile and, above all, requirements necessary for the performance of the functions.

It is noteworthy that not all environments provide the condition of forming leaders, this action developed by people management makes internal recruitment possible through leadership, that the employee has autonomy and decision-making ahead of the other team, thus harmonizing the environment, leaving it adequate and mainly able to increase the profitability and productivity of others (LEITE, 2019).

\subsection{OPTIMISATION IN MANAGEMENT IN PEOPLE BY IT GOVERNANCE}

The management of people over the years has undergone adaptations resulting from profound transformations that may involve the implementation of actions to obtain results. According to Wanzerller et al. (2018), the origin of the name management comes from the Latin "gestione", which defines its meaning as an act or effect of managing or managing or managing and person of the Latin "persona" that indicates a man or woman.

Since the 1980s, globalization has taken over the economic scenario, with the evolution of communications, technological development and competitiveness. This technological advent has led several companies to acquire new knowledge about information technologies in organizations. Therefore, people management is a managerial function that covers the participation of people within organizations in

RC: 93820

Disponível em: https://www.nucleodoconhecimento.com.br/business- 
order to achieve the objectives and organizational and individual objectives desired (POCHMANN, 2015; STECCA, 2014).

Pessoa et al. (2017, p. 02), describes that:

It is important today that organizations use technology tools to solve support their business. With technological advancement, the tools have become powerful and to some extent captivating, by ease of use and integration with various systems. Professionals need to use tools to assist them in the day-to-day life of the company.

For the company to have a good development it is necessary that all departments are aligned, with a manager active in each department. The personnel management department exerts great importance for an organization, because through it the entire work team is recruited and selected, in addition to involving everything that is connected to the company, whether internally or externally: environment, policies, society and competitors (REIS et al., 2018).

Worldwide, companies look through technological tools, a way to maximize their business, focusing on their performance, effectiveness, customer satisfaction, profitability and service efficiency. Within the business systems we can perceive that the evaluative forms are consolidating the work performed by people management, a concept widely defended by several authors as speaks Lima and Figueiredo (2020) when elaborating the dissertation that only evaluating what was done in the course of a given time can be identified the productivity achieved in the sectors.

In this sense, the improvement of the quality of organizations in recent decades through technologies, has been bringing benefits to the business market, such as: optimization of services, better employee performance, competitiveness, maximization of results among others (OLIVEIRA; VASCONCELOS, 2005). In this context, corporate governance has become the structure that aims to ensure decisions in relation to the organization, thus ensuring the interests of stakeholders (BARROS; DA SILVA, GOESE, 2015).

RC: 93820

Disponível em: https://www.nucleodoconhecimento.com.br/business- 
IT governance has brought innovation to people management. Novato (2014) mentions that IT Governance has been classified as being a set of elements that bring practices, standards and structured relationships, which are directed by managers and IT technicians, aiming at ensuring organizational controls, expanding performance and security processes, minimizing risks and optimizing the application of resources, which brings IT into a business-driven alignment.

Therefore, new technologies suggest transformations not only in business processes, but also in the way products and services are created and marketed, the structure and goals of the company, the dynamics of competition and the very nature of the business and its employees (TIDD; BESSANTE, 2015; KON, 2016).

Thus, IT governance has been pointing out as an effective and safe tool in the management of people for the formatting of the organizational structure, involving the definition of people to reach the professional framework of the organization, so that a harmonic work division can be developed by this team with responsibility aiming in common the growth of the company (LORENZETTI et al., 2014).

\subsection{SOCIAL NETWORKS FOR THE RECRUITMENT AND SELECTION OF A COMPANY}

When referring information and communication technologies to the recruitment of people, it is said that technologies have been facilitating the lives of many organizations, assisting in the selection of good professionals. The potential of technologies, for good recruitment and selection, is increasingly being used. Dos Santos; De Oliveira and Centurión (2018) point out that technologies emerge as allies in the recruitment and selection of personnel. Through technological means it is possible that people can seek jobs and be selected.

The use of social networks for the selection of curriculum according to Lago; Da Silva e Barbosa (2018) is becoming increasingly real, since, from the use of social

RC: 93820

Disponível em: https://www.nucleodoconhecimento.com.br/business- 
networks, there is a greater scope of people for the selection of the position offered, which allows to find the ideal employee for the desired position in the company.

Queiróz and Sanches (2019, p. 472) mention that:

Concomitantly with the technologies, social networks have emerged, where it is possible to become aware of people's personal lives in real time; Twitter, Instagram, Facebook, you can hardly find someone who doesn't have at least one of these social networks these days. Because of this, it is common that in selection processes networks are used to draw a personal profile of the candidate according to their posts, being a criterion for exclusion of candidates.

In Melo's perception (2014), social networks were initially seen as instruments of meetings and reunions in a society based on the distance between people due to globalization. However, the present day allows social networks to be not only for these purposes, but extend their conceptions and evolve enabling knowledge and contact between strange people with specific groups of interest.

An example of the use of social networks is observed in online recruitment. Online recruitment is a tool that differs from traditional recruitment because it is a technique used, associated with technologies such as the Internet. This type of recruitment aims to disclose vacancies and select people only through virtual networks (DE LIMA: RABELO, 2018).

Pedroso (2016, p. 25), describes that:

Online recruitment is a rapidly growing method as more and more individuals make their Curriculum Vitae (CV) available in the online marketplace because they recognise their potential. The success of this method is intrinsically related to the fact that companies can reach a larger pool of candidates with potential since geographical restrictions are less significant, i.e. individuals can be approached by companies from anywhere in the world as well as can apply for employment from any area of the globe.

Cassiano; Lima and Zupani (2016) identify that the way in which the dissemination on social networks for the occurrence of recruitment occurs is considered passive.

RC: 93820

Disponível em: https://www.nucleodoconhecimento.com.br/business- 
This form of recruitment takes place from the dissemination of the employee on social media, one of these media relates to Facebook and Instagram. Another passive recruitment involves linkedin'ssocial network, in this social network the candidate is selected by his profile reference in which his qualifications appear. It is worth noting that these recruitments are made by social networks and that each social network brings a differentiated characteristic about the candidate, therefore, it is up to the recruiter to know if they are direct before the choice of their candidates for selection.

De Lima and Rabelo (2018, p. 06) states that:

E-recruitment can also provide constant information to candidates regarding job opportunities from different areas and organizations. Traditional recruitment is often published in newspaper and magazine advertisements that require limited numbers of characters or information. In this sense, online recruitment can be considered a source of clarity and also a dynamic way, because one can disseminate links that direct candidates to relevant content about the organization.

Lago; Da Silva Manhães and Barbosa (2018) mention in their research that social networks and media optimize the recruiter's time and the selection of people. The use of technological tools enhances the approximation between the company and the candidate bringing agility in the dissemination of vacancies and in the receipt of resumes to be selected.

According to Oliveira (2013, p. 38):

Good interpersonal relationships are one of the factors that influence the satisfactory performance of a group's daily productions. A team that works together for the same goal achieves with quality and efficiency what is proposed by its leader.

In this sense, it is essential that the manager knows closely the anides and objectives of each employee for the organization. This is so that there are no legal discomforts

RC: 93820

Disponível em: https://www.nucleodoconhecimento.com.br/business- 
when identifying something that can not bring benefits to the organization, or even on the contrary, the employee is the target of something undesirable.

\section{FINAL CONSIDERATIONS}

The research carried out brought up a relevant subject about recruitment and selection in organizations within the changes resulting from technology. People management is a sector in which the entire human resources process develops, in this environment, the search for the ideal employee begins.

Given the changes in globalization, the recruitment and selection of people have been marked by new techniques of choice, among these new techniques that until then were face-to-face, social networks gain space, knocking down geographical obstacles and expanding competition for the intended vacancy.

It becomes evident that the use of technologies assumes a relevant role in hiring this employee, through social networks, a potential tool for recruitment and selection, make technologies an ally in decision making.

Facebook, Instagram, Twitter, Linkedin and other social networks have been noticed by recruiters in order to find the ideal candidate. However, each social network has its characteristic and that the recruiter should know how to target each social network seeking the ideal candidate for their company.

It is concluded, therefore, that social networks are technological tools that help the management of people in search of their candidates. It is emphasized the importance of extending this study based on scientific evidence, in which research can be carried out within companies that make use of social networks to monitor their employees.

\section{REFERENCES}

\section{ALBERTON, Luiz. Uma contribuição para a formação de auditores contábeis}

RC: 93820

Disponível em: https://www.nucleodoconhecimento.com.br/business- 
independentes na perspectiva comportamental. 2002. 270 f. Monografia (Programa de Pós-Graduação em Engenharia de Produção). Universidade Federal de Santa Catarina. 2002.

BARROS, Claudio Marcelo Edwards; DA SILVA, Pedro Ylunga Costa; VOESE, Simone Bernandes. Relação entre o custo da dívida de financiamentos e governança corporativa no Brasil. Journal of Accounting, Management and Governance, v. 18, n. 2, 2015.

CANALLI, Tiago; DE ANDRADE, Érica Fernanda Pereira. Recrutamento interno: uma nova perspectiva sobre plano de carreira. Revista Eletrônica Organizações e Sociedade, 2016, 5.3: 88-100.

CARVALHO, leda Maria Vecchioni. Recrutamento e seleção por competências. Rio de Janeiro: Editora FGV, 2015.

CASSIANO, Cecilia Nascimento; LIMA, Luciana Campos; DOS SANTOS ZUPPANI, Tatiani. A eficiência das redes sociais em processos de recrutamento organizacional. NAVUS-Revista de Gestão e Tecnologia, v. 6, n. 2, p. 52-67, 2016.

CHIAVENATO, Idalberto. Recursos humanos.7 ed. São Paulo: Atlas, 2002.

COSTA, Esdras da Silva et al. Análise das relações e ações conjuntas entre as empresas do APL têxtil da região metropolitana de São Paulo: contribuições para o seu crescimento. Interações (Campo Grande), v. 19, p. 401-415, 2018.

DE BEM NORO, Greice; STÜKER, Camila; DE OLIVEIRA, João Helvio Righi. A relação das características inerentes aos perfis de liderança no desenvolvimento do processo coaching. Revista Capital Científico-Eletrônica (RCCe) - ISSN 2177 4153, v. 13, n. 1, p. 59-76, 2015.

RC: 93820

Disponível em: https://www.nucleodoconhecimento.com.br/business- 
DE LIMA, Aryane Santos Henriques; RABELO, Aline Andrade. A importância do erecrutamento e seleção online no processo organizacional. Revista Psicologia,Diversidade e Saúde, v. 7, n. 1, p. 139-148, 2018.

DOS SANTOS, Márcia Gomes; DE OLIVEIRA, Rodrigo Cesar Reis; CENTURIÓN, Wanusa Campos. Recrutamento e seleção estratégicos: processos tradicionais e a influência das mídias sociais. Ideias e Inovação-Lato Sensu, v. 4, n. 3, p. 57, 2018.

KON, Anita. Ecossistemas de inovação: a natureza da inovação em serviços. Revista de Administração, Contabilidade e Economia da Fundace, v. 7, n. 1, 2016.

LAGO, Barbara; DA SILVA MANHÃES, Ana Claudia Tavares; BARBOSA, Marcus Vinicius. O uso de novas tecnologias digitais no recrutamento e seleção de talentos. Revista Interdisciplinar em Gestão, Tecnologia e Saúde, v. 1, n. 01, p. 161-178, 2018.

LEAL, Débora Ribas; MATTOS, Gisele Domingues de; FONTANA, Rosane Teresinha. Trabalhador com deficiência física: fragilidades e agravos autorreferidos. Revista brasileira de enfermagem, v. 66, n. 1, p. 59-66, 2013.

LEITE, André Mourão. O impacto da transformação digital na gestão de pessoas: abordagens estratégicas para atrair, reter e motivar talentos da área de TI na região da grande Florianópolis. Gestão de pessoas-Unisul Virtual, 2019.

LIMA, Ricardo Leite; FIGUEIREDO, Giane Lourdes Alves de Souza. Novas estratégias do marketing 4.0 para as organizações. Facit Business and Technology Journal, v. 1, n. 21, 2020.

LORENZETTI, J. et al. Organização do trabalho da enfermagem hospitalar: abordagens na literatura. Texto Contexto Enferm., Florianópolis, v.23, n. 4, p. 110412, out-dez, 2014.

RC: 93820

Disponível em: https://www.nucleodoconhecimento.com.br/business- 
MELO, Cristiane Maria Freitas de. Freedom of expression on social networks: right to criticism of the employee versus image and honor of the employer. 2014. 136 f. Dissertação (Mestrado em Direito) - Pontifícia Universidade Católica de São Paulo, São Paulo, 2014.

MOTTA, Marlton Fontes, et al. O Uso das Redes Sociais no Ambiente de Trabalho e as Estratégias da Gestão de Pessoas para a Gestão de Resultados. In: Congresso de Gestão, Negócios e Tecnologia da Informação-CONGENTI. 2017.

MOZER, André Emílio. Recrutamento e seleção-uma proposta para recrutamento e seleção interno. Gestão em Foco: Revista Eletrônica On Line. Amparo: SP, 2016, 8.1.

NOVATO, Douglas. 0 que é Governança de TI? OFICINA DA NET. 2014.Disponível em: https://www.oficinadanet.com.br/post/12712-o-que-egovernanca-de- Acesso em: 13/mai/2021

OLIVEIRA, Camila Miles; BUENO, Rose Ângela Vieira Passos. Uma análise da contribuição dos testes psicológicos no processo de recrutamento e seleção de pessoal. Simpósio de Produções Acadêmicas em Psicologia do Univag, n. 1, 2018.

OLIVEIRA, Rosane S. O papel do gestor na motivação dos seus colaboradores. Cairu em Revista. Jan 2013, Ano 02, nº2, p. 33-41, ISSN 22377719.

PEDROSO, Rita Cipriano. Redes sociais e recrutamento. 2016. 81 f. Tese de Doutorado. Universidade Católica de Portugal. Porto, Portugal, 2016.

PESSOA, Cláudio Roberto Magalhães et al. Da gestão de TI à gestão de informação e tecnologia: uma abordagem teórica da evolução do conceito= From management of technology and information to a management of information and technology: a theoretical approach of concept development. Descobrimentos da Ciência da

RC: 93820

Disponível em: https://www.nucleodoconhecimento.com.br/business- 
Informação: desafios da Multi, Inter e Transdisciplinaridade (MIT): XVII Encontro Nacional de Pesquisa em Ciência da Informação (ENANCIB), 2016.

POCHMANN, Márcio. 0 emprego na globalização: a nova divisão internacional do trabalho e os caminhos que o Brasil escolheu. Bomtempo Editorial, 2015.

PORTO, Daniel da Silva et al. Gestão de pessoas: o caso da empresa Yes Contact Center no Município de Florianópolis/SC-Brasil. 2016. Dissertação de Mestrado.

QUEIRÓZ, Monique Mazon; SANCHES, Nathalia Paes. As influências das redes sociais no direito do trabalho. Revista do Tribunal Regional do Trabalho da 15a Região, n. 55, p. 271-280. 2019

REIS, Thompson Augusto, et al. Endomarketing, Liderança e Comunicação: reflexos na organização. Caderno Profissional de Marketing-UNIMEP, 2018, 6.1: 1-17.

RIBEIRO, Antonio de Lima. Gestão de pessoas. Saraiva Educação SA, 2017.

SANTOS, Suênia Soares. Recrutamento e seleção: um estudo do impacto da tecnologia praticado por hotéis da orla de João Pessoa-PB. 2018. $44 \mathrm{f}$. Monografia (Graduação em Hotelaria). Universidade Federal da Paraíba. Paraíba. 2018.

SILVA, Bruno de Oliveira Fernandes da, et al. Teoria das Organizações. 2020. 46 f. USP - Universidade de São Paulo. Faculdade de Economia, Administração e Contabilidade - FEA-RP. São Paulo. 2020.

SILVA, Jessyca Rodrigues Henrique da. Impactos da tecnologia nos processos de gestão de pessoas: um estudo no setor hoteleiro. 2019. 129f. Dissertação (Mestrado em Turismo) - Centro de Ciências Sociais Aplicadas, Universidade Federal do Rio Grande do Norte, Natal, 2019.

RC: 93820

Disponível em: https://www.nucleodoconhecimento.com.br/business- 
SILVA, Vanessa; FERRETT, Kézia; MANCINI, Ronaldo. Recrutamento e Seleção: Um estudo sobre as técnicas utilizadas nas organizações. ETIC-ENCONTRO DE INICIAÇÃO CIENTÍFICA, 10.10. 2014.

SPADER, Gabriele A influência da competência profissional, da inteligência emocional, da produtividade e do engajamento sobre a satisfação com o trabalho em um ambiente de serviços de saúde. 2019. 93 f. Dissertação (Mestrado em Administração). Universidade de Caxias do Sul. 2019.

STECCA, Jaime Peixoto. Estratégias genéricas na gestão de pessoas e comprometimento organizacional: um estudo em sociedades cooperativas de crédito. 2014. 144 f. Tese. (Doutorado em Administração, Economia e Contabilidade). Universidade de São Paulo. 2014

TIDD, Joe; BESSANT, Joe. Gestão da inovação-5. Bookman Editora, 2015.

WANZERLLER, Rafaela et al. Gestão de pessoas: visão estratégica sobre treinamento e desenvolvimento no contexto das organizações do século XXI. Revista de Administração e Negócios da Amazônia, v. 10, n. 2, p. 67-84, 2018.

Submitted: May, 2021.

Approved: July, 2021.

RC: 93820

Disponível em: https://www.nucleodoconhecimento.com.br/business- 